\title{
The Effect of Vibro-Activation Time on the Properties of Highly Active Calcium Hydroxide
}

\author{
Yaroslav Yakymechko ${ }^{1}$, Iryna Lutsyuk ${ }^{2}$, Roman Jaskulski ${ }^{1, * \mathbb{C}}$, Judyta Dulnik ${ }^{3}$ and \\ Tetyana Kropyvnytska ${ }^{4}$ \\ 1 Faculty of Civil Engineering, Mechanics and Petrochemistry, Warsaw University of Technology, \\ 09-400 Płock, Poland; Yaroslav.Yakymechko@pw.edu.pl \\ 2 Institute of Chemistry and Chemical Technologies, Lviv Polytechnic National University, \\ 79000 Lviv, Ukraine; iryna.v.lutsiuk@lpnu.ua \\ 3 Laboratory of Polymers and Biomaterials, Institute of Fundamental Technological Research Polish Academy \\ of Sciences, 02-106 Warsaw, Poland; jdulnik@ippt.pan.pl \\ 4 Institute of Civil Engineering and Building Systems, Lviv Polytechnic National University, \\ 79000 Lviv, Ukraine; tkropyvnytska@ukr.net \\ * Correspondence: Roman.Jaskulski@pw.edu.pl
}

Received: 18 May 2020; Accepted: 11 June 2020; Published: 16 June 2020

\begin{abstract}
The results of studying the effect of the vibration processing time on the size of calcium hydroxide particles are given. The physicochemical processes affecting the size and morphology of calcium hydroxide particles have been studied. A stage-by-stage mechanism of the process of the carbonation of lime, depending on its specific surface, is established. The results show that the optimal period for the vibration treatment of lime to obtain the most active material is $20 \mathrm{~min}$. A longer period of vibration results in the merging of particles into larger agglomerates.
\end{abstract}

Keywords: lime; portlandite; vibration treatment; carbonation; crystallization

\section{Introduction}

Highly dispersed hydrated lime (nano-lime) is widely used in various sectors of the economy [1-4], in particular, for the restoration of ancient monuments made of marble and carbonate-containing rocks [1,5,6] as an effective sorbent [3], for the deacidification of soil [7,8], as a consolidant for lime mortars $[9,10]$, as a means of thermochemical heat energy storage due to cycles of hydration/dehydration of $\mathrm{CaO} / \mathrm{Ca}(\mathrm{OH})_{2}[11]$ etc.

Nanoparticles of hydrated lime have specific properties and, above all, a high rate of carbonation. During the treatment of cracks and damages in rocks with nano-lime suspension, a protective dense layer of calcium carbonate and portlandite is formed, increasing in volume, which contributes to the filling of free space and increasing of the strength of the stone [12]. The adhesion of the layer of the carbonized lime to the surface of the material increases as the process of carbonation develops [13]. At the same time, it should mentioned that the content of calcium hydroxide particles with sizes less than $100 \mathrm{~nm}$ in nano-lime is small, and therefore, the special properties of $\mathrm{Ca}(\mathrm{OH})_{2}$ nanoparticles are not being fully exploited.

The technology for obtaining calcium hydroxide with particle sizes less than $100 \mathrm{~nm}$ is complex and characterized by high energy costs, which significantly restrains the widespread use of such lime. Research in this direction has been conducted by scientists from India, Italy, France, Canada, China, Spain, Iran, Malaysia and Qatar [2,14-26] and aimed i.a. at studying the influence of the hydration environment on the characteristics of $\mathrm{Ca}(\mathrm{OH})_{2}$ obtained. It has been found out that the most effective way to obtain $\mathrm{Ca}(\mathrm{OH})_{2}$ particles with dimensions of $50-400 \mathrm{~nm}$ is the reaction between $\mathrm{CaCl}_{2}$ and 
$\mathrm{NaOH}$ in the environment of ethylene glycol, polyoxyethylene, 1,2-propanol and 2-propanol [2,18]. When $\mathrm{NaOH}$ and $\mathrm{Ca}\left(\mathrm{NO}_{3}\right)_{2} \cdot 2 \mathrm{H}_{2} \mathrm{O}$ interact in an aquatic environment at a temperature of $30^{\circ} \mathrm{C}$, it is possible to obtain nanoparticles of lime with sizes up to $200 \mathrm{~nm}$ [2]. It is claimed that in aqueous solutions, nanoparticles of lime are unstable, because they consolidate to form aggregates with sizes of up to 1-2 microns [27]. To stabilize the water suspensions of $\mathrm{Ca}(\mathrm{OH})_{2}$, it is recommended to introduce a certain amount of finely dispersed $\mathrm{CaCO}_{3}$. In this case, there is a physical and chemical interaction between the components, there is a change in the $\zeta$-potential of calcium hydroxide, and the stability of the system increases.

The purpose of this work is to study the effects of the duration of vibro-treatment on the process of lime carbonation and study the physical and chemical processes that affect the size and morphology of $\mathrm{Ca}(\mathrm{OH})_{2}$ particles.

\section{Materials and Methods}

In this work, hydrated lime was obtained by slaking the ground quicklime of the company Lhoist (Poland), type CL 90-Q, at a CaO/ $\mathrm{H}_{2} \mathrm{O}$ ratio of 1:1. The contents of basic oxides in quicklime in $\%$ were as follows: $\mathrm{CaO}-91.9, \mathrm{MgO}-1.6$, the sum of active $\mathrm{CaO}+\mathrm{MgO}-89.6, \mathrm{CO}_{2}-1.4$ and $\mathrm{SO}_{3}-0.2$. The obtained paste-like mass of hydrated lime with a water content of $600 \mathrm{~g}$ in $1 \mathrm{~kg}$ of ready mixture was subjected to vibro-treatment with the use of a toroidal type vibro-activator operating in resonance mode. The frequency of fluctuations of the working chamber with blades was $25 \mathrm{~Hz}$, and the amplitude of the fluctuations was $1.00-1.75 \mathrm{~mm}$. The vibration processing time for different samples was changed from 10 to $45 \mathrm{~min}$.

The granulometry of the original quicklime, its hydration products, and hydrated lime particles after vibrating treatment were studied with the Mastersizer 3000 laser diffraction particle size analyzer. The suspension used in granulometric studies was obtained by the dispersion of the obtained products in ethanol ( $98 \%)$ with the help of the ultrasonic processor VCX500 by SONIKS. The power of the processor was $150 \mathrm{~W}$; the resonance frequency, $20-50 \mathrm{kHz}$; and the diameter of the conical generating nozzle, $6 \mathrm{~mm}$. The processing time was changed from 1 to $5 \mathrm{~min}$.

The BIOLAR-EPI optical microscope was used to study the results of processes occurring during the vibro-treatment of lime suspensions, to determine the size and shape of $\mathrm{Ca}(\mathrm{OH})_{2}$ particles and to determine the crystallographic characteristics of crystals. To prepare samples for optical microscopy, lime suspension was prepared in ethyl alcohol (98\%) or glycerol using an ultrasonic microwell nozzle with a diameter of $2 \mathrm{~mm}$ and a processing time of $30 \mathrm{~s}$. The structure and morphology of portlandite crystals were also studied using the scanning electron microscope JSM-6010PLUS/LA InTouchScope.

The quicklime used in the work has a particle size of $\mathrm{CaO}$ from $100 \mathrm{~nm}$ to 500 microns. The number of $\mathrm{CaO}$ particles with sizes from 45 to 200 microns was the largest and was up to $55 \%$. The number of $\mathrm{CaO}$ particles with sizes from $100 \mathrm{~nm}$ to 32 microns was much smaller-up to $28 \%$ (Table 1 ). When quicklime was slaked, the specific surface area almost doubled, and the largest number of formed particles were those with sizes of 0.1-32 microns.

Table 1. Specific surface and granulometric composition of quicklime and hydrated lime.

\begin{tabular}{ccccccccc}
\hline \multirow{2}{*}{ Material } & \multirow{2}{*}{$\begin{array}{c}\text { Specific Surface, } \\
\left(\mathbf{m}^{\mathbf{2}} \mathbf{/ k g}\right)\end{array}$} & \multicolumn{7}{c}{ Particle Content, \%, in Range $(\boldsymbol{\mu m})$} \\
\cline { 3 - 9 } & $\mathbf{5 0 0 - 1 0 0 0}$ & $\mathbf{2 0 0 - 5 0 0}$ & $\mathbf{9 0 - 2 0 0}$ & $\mathbf{6 3 - 9 0}$ & $\mathbf{4 5 - 6 3}$ & $\mathbf{3 2 - 4 5}$ & $\mathbf{0 . 1 - 3 2}$ \\
\hline Quicklime & 282.0 & 0.01 & 9.76 & 31.93 & 13.42 & 9.59 & 7.14 & $\mathbf{2} 8.15$ \\
Hydrated lime & 522.5 & 0.00 & 0.00 & 5.28 & 8.59 & 8.84 & 7.76 & 69.53 \\
\hline
\end{tabular}

The study of the process of the carbonation of hydrated lime and the influence of the vibro-activation time on the speed of this process was also carried out. It was performed by a specially developed method. Samples in the form of cubes with an edge of $10 \mathrm{~mm}$ were prepared from lime paste with a constant water-lime ratio of 0.5 and were used for the testing. After $24 \mathrm{~h}$ from preparation, the samples 
were removed from the molds and stored for $48 \mathrm{~h}$ in a desiccator above the layer of soda lime (a mixture of sodium hydroxide and calcium oxide, which absorbs moisture and carbon dioxide from the air). At the same time, the weight of the samples was constantly controlled by means of weighing on the electronic scales with an accuracy of $\pm 0.01 \mathrm{~g}$. After $72 \mathrm{~h}$ from the beginning of sample preparation, they were attached on one side to a pre-weighed metal plate. The plates with samples were placed in a thermostatic chamber with a temperature of $20 \pm 2{ }^{\circ} \mathrm{C}$ and a controlled relative humidity of $70 \pm 5 \%$. After placing the samples in the chamber, weighing was performed every $12 \mathrm{~h}$. The weight gain of the samples was taken as the formed amount of calcium carbonate according to the reaction $\mathrm{Ca}(\mathrm{OH})_{2}+$ $\mathrm{CO}_{2} \leftrightarrow \mathrm{CaCO}_{3}+\mathrm{H}_{2} \mathrm{O}$.

\section{Results}

The average diameters of quicklime particles, hydrated lime particles and also hydrated lime particles activated at different times were calculated. As can be seen in Table 2, quicklime is characterized by a high content $(1.95 \%)$ of ultra-disperse fraction of size less than 0.5 microns in comparison with other tested forms of lime. It is worth noting that the hydrated lime fraction of $1 \mu \mathrm{m}$ is equal to $1.26 \%$, and this is the lowest content of particles of this size in all the cases. In the process of the activation of hydrated lime, 10 and 20 min-long processing increased the content of particles up to 1 micron by 2.3 and 6.0 times, respectively. In the case of lime activated for 20 and $45 \mathrm{~min}$, the fractions up to $0.5 \mu \mathrm{m}$ are $0.23 \%$ and $0.14 \%$, respectively. The effective diameters of $\mathrm{d} 10, \mathrm{~d} 50$ and $\mathrm{d} 90$ for hydrated lime activated for $10 \mathrm{~min}$ were 1.56, 6.27 and $55.6 \mu \mathrm{m}$, respectively, while for lime activated for the optimal time ( $20 \mathrm{~min})$, these diameters were reduced by 1.2-1.7 times.

Commonly used parameters, calculated automatically by the Mastersizer 3000 laser diffraction particle size analyzer software, were used to describe the granulometry results. The mean diameters $\mathrm{D}[4 ; 3]$ and $\mathrm{D}[3 ; 2]$ are defined by Equations (1) and (2):

$$
\begin{aligned}
& \mathrm{D}[4 ; 3]=\frac{\sum \mathrm{v}_{\mathrm{i}} \cdot \mathrm{D}_{\mathrm{i}}^{4}}{\sum \mathrm{v}_{\mathrm{i}} \cdot \mathrm{D}_{\mathrm{i}}^{3}} \\
& \mathrm{D}[3 ; 2]=\frac{\sum \mathrm{v}_{\mathrm{i}} \cdot \mathrm{D}_{\mathrm{i}}^{3}}{\sum \mathrm{v}_{\mathrm{i}} \cdot \mathrm{D}_{\mathrm{i}}^{2}}
\end{aligned}
$$

in which $v_{i}$ is the percentage of the volume of particles with an average diameter of $D_{i}$ in the total volume occupied by the tested sample. The effective diameters d10, d50 and d90 are calculated as the 10th, 50th and 90th percentiles of the particle volume distribution in the sample. The fraction content is calculated as cumulative sum of the volume of particles whose diameters are lower than the values given in the table.

\begin{tabular}{|c|c|c|c|c|c|c|c|c|c|c|c|}
\hline \multirow[t]{2}{*}{$\begin{array}{c}\text { Type } \\
\text { of Lime }\end{array}$} & \multicolumn{6}{|c|}{ Fraction Content (\%) } & \multicolumn{2}{|c|}{$\begin{array}{c}\text { Estimated Volume } \\
\text { of Average } \\
\text { Diameter }(\mu \mathrm{m})\end{array}$} & \multicolumn{3}{|c|}{$\begin{array}{l}\text { Effective } \\
\text { Diameters } \\
(\mu \mathrm{m})\end{array}$} \\
\hline & $<0.5 \mu \mathrm{m}$ & $<1 \mu \mathrm{m}$ & $<5 \mu \mathrm{m}$ & $<10 \mu \mathrm{m}$ & $<20 \mu \mathrm{m}$ & $<60 \mu \mathrm{m}$ & $\mathrm{D}[3 ; 2]$ & D [4;3] & d10 & d50 & d90 \\
\hline Quicklime & 1.95 & 2.99 & 9.58 & 14.6 & 21.4 & 46.6 & 6.63 & 89.7 & 5.36 & 73.0 & 198 \\
\hline Hydrated & - & 1.26 & 39.4 & 52.5 & 63.67 & 89.5 & 4.95 & 25.4 & 1.88 & 9.31 & 73.1 \\
\hline $\begin{array}{l}\text { Activated } \\
\text { for } 10 \mathrm{~min}\end{array}$ & - & 2.94 & 46.4 & 59.4 & 70.3 & 93.7 & 3.93 & 18.6 & 1.56 & 6.27 & 55.6 \\
\hline $\begin{array}{l}\text { Activated } \\
\text { for } 15 \mathrm{~min}\end{array}$ & - & 3.23 & 40.7 & 54.0 & 65.8 & 86.4 & 3.80 & 18.6 & 1.53 & 5.86 & 53.7 \\
\hline $\begin{array}{l}\text { Activated } \\
\text { for } 20 \mathrm{~min}\end{array}$ & 0.23 & 7.57 & 48.3 & 64.1 & 78.6 & 100 & 3.24 & 11.7 & 1.27 & 5.61 & 31.9 \\
\hline $\begin{array}{l}\text { Activated } \\
\text { for } 45 \mathrm{~min}\end{array}$ & 0.14 & 6.06 & 50.1 & 60.5 & 70.6 & 91.8 & 3.38 & 20.3 & 1.35 & 5.18 & 59.7 \\
\hline
\end{tabular}

Table 2. Granulometric composition of lime. 
The calculated average volume diameter of $\mathrm{D}[4 ; 3]$ for quicklime is $89.7 \mu \mathrm{m}$, and for hydrated lime it is $25.4 \mu \mathrm{m}$, while in case of lime activated for 10 to $45 \mathrm{~min}$, it varies between 3.93 and $3.24 \mu \mathrm{m}$. The maximum average diameter $\mathrm{D}[3 ; 2]$ of the particle distribution over the specific surface area for quicklime is $6.63 \mu \mathrm{m}$, while for hydrated lime, it is reduced 1.3 times, and for hydrated lime activated at the optimal time, by 2 times.

As can be seen in Figure 1, hydrated lime, as well as activated lime, is characterized by a bimodal distribution of particle dimensions. For hydrated lime, the amount of fine lime within the range of $0.75-10 \mu \mathrm{m}$ was $52.53 \mathrm{vol} \%$, and for lime activated for $10-15 \mathrm{~min}$, the amount of fine lime particles $(0.9-10.0 \mu \mathrm{m})$ varied within the range of $59.39 \mathrm{vol} \%$ to $54.02 \mathrm{vol} \%$. For quicklime and lime activated for 20-45 $\mathrm{min}$, the ultra-dispersed fractions of $0.11-1.0$ and $0.75-1.0$ microns appeared with their contents of $1.95 \mathrm{vol} \%$ and $0.23 \mathrm{vol} \%$, respectively.
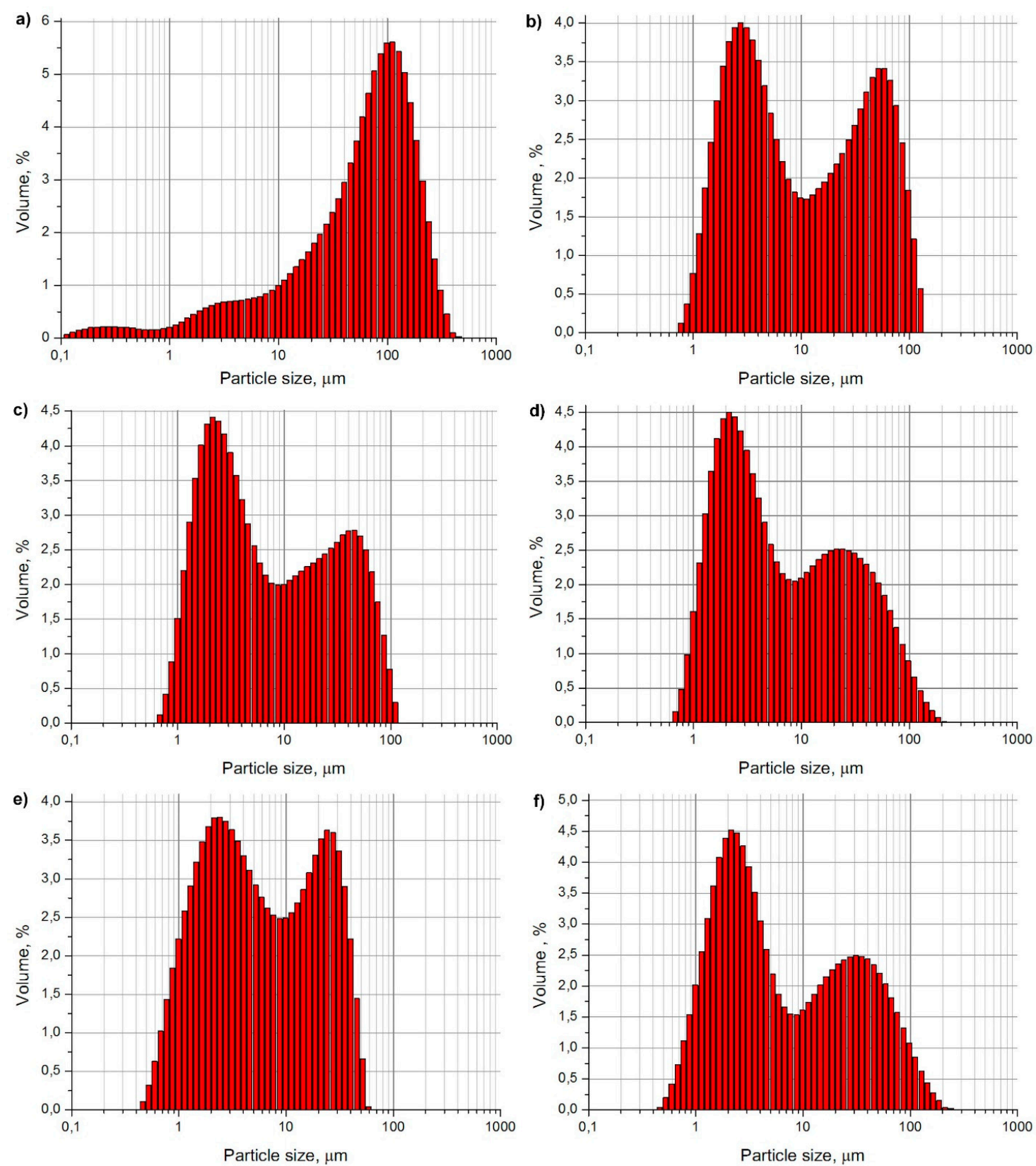

Figure 1. Particle size distribution for quicklime (a), hydrated lime (b) and hydrated lime activated for $10 \mathrm{~min}(\mathbf{c}), 15 \mathrm{~min}(\mathbf{d}), 20 \mathrm{~min}(\mathbf{e})$ and $45 \mathrm{~min}(\mathbf{f})$. 
Upon the interaction of lime with water, there is a transformation of the cubic crystal lattice of $\mathrm{CaO}$ into a hexagonal one for $\mathrm{Ca}(\mathrm{OH})_{2}$. The reaction proceeds mainly through the topochemical mechanism [28] with the formation of crystals in the form of hexagonal plates. The overwhelming majority of the hydrated lime formed is particles with sizes of $2-4$ microns, which form larger aggregates with sizes of 30-40 microns as a result of attraction due to Van der Waals forces.

In the study of calcium hydroxide suspension in an optical microscope (Figure 2), it is seen that $\mathrm{Ca}(\mathrm{OH})_{2}$ particles with sizes of 2-4 microns as a result of Van der Waals forces are connected by dipoles, forming a spatial grid. Smaller particles form chains of complex configuration. After vibro-treatment, their size decreases by 2.0-3.5 times, and at the same time, there is a complete destruction of the structure and alignment of the particle size.
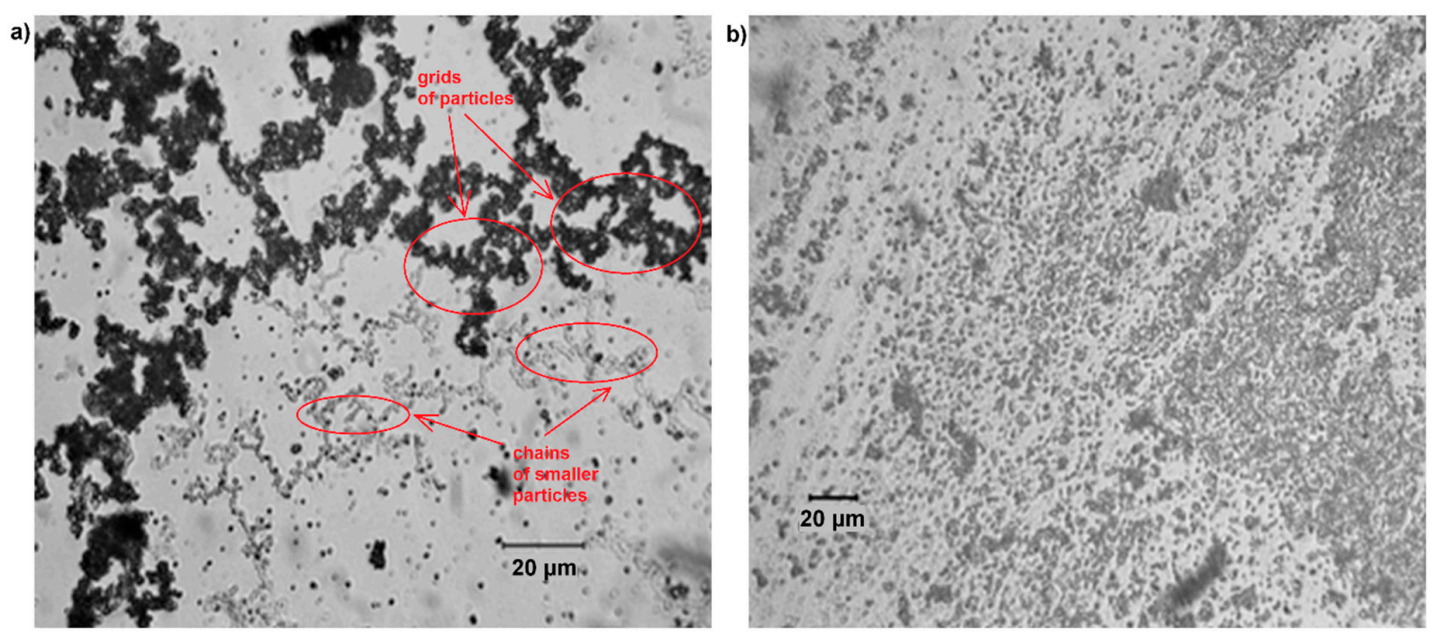

Figure 2. Particles of calcium hydroxide obtained during hydration of $\mathrm{CaO}$ (a) and after vibration treatment within $20 \mathrm{~min}(\mathbf{b})$.

After the increase in the time of vibro-treatment of hydrated lime from 20 to $45 \mathrm{~min}$, the increase in the size of particles due to their aggregation is observed. At the same time, the maximum volume average diameter of D [4; 3] increases significantly (from 11.7 to 20.3 microns), and the maximum size of aggregated particles increases from 70 to 230 microns. These are undesirable phenomena, hence the conclusion that extending the vibro-activation time beyond $20 \mathrm{~min}$ is not advantageous.

Thus, the maximum vibrating time is $20 \mathrm{~min}$. Further increases in time do not have a positive effect. For example, in the case of a 45-min vibrating process, the inverse effect occurs-the consolidation of activated lime particles. This can be explained by the fact that hydrated lime in the aquatic environment has dipole properties, but during long-term vibro-treatment, there is a process of destruction of dipoles, a redistribution of charges on their surface and their subsequent secondary grouping [29].

Unlike the structure, the configuration of the particles after the vibrating treatment practically does not change (Figure 3), and only the destruction of individual units occurs, which is accompanied by a general reduction in the size of the particles. Furthermore, it is shown that the vibro-treated lime is characterized by higher chemical activity (as shown by the example of the carbonation process) than lime, which was not treated in such a way.

In this paper, we also studied the process of the carbonation of samples obtained from calcium hydroxide with different activation times. It is known that the process of lime carbonation is accompanied by an increase in its mass. It allows the investigation of the process of the interaction of lime with $\mathrm{CO}_{2}$ from air by the gravimetric method. The specific feature of this method is the holding of samples at constant humidity and temperature, and the control of the sample mass. The main disadvantage of this method is that measurements can be made only after $72 \mathrm{~h}$ from preparation of the samples. It is connected with the fact that during this time, as established by us, there is a complete evaporation of water and stabilization of the sample mass. 

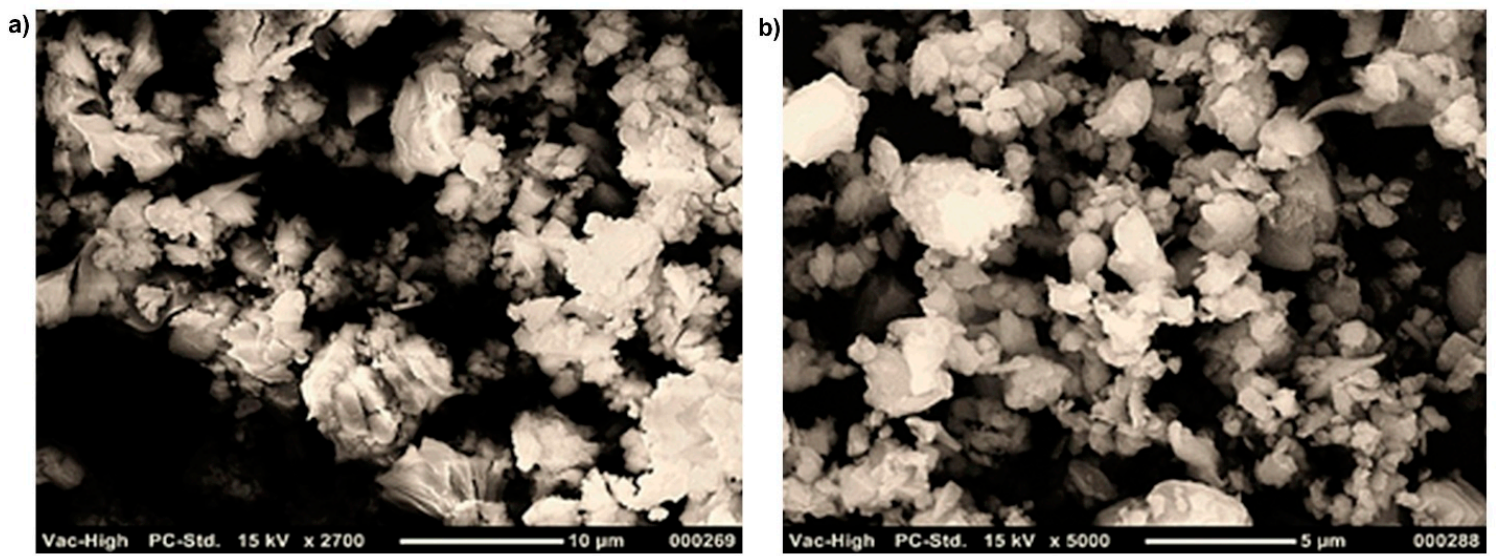

Figure 3. SEM microphotographs of calcium hydroxide particles obtained during the hydration of $\mathrm{CaO}$ (a) and after vibration treatment for $20 \mathrm{~min}(\mathbf{b})$.

The studies were carried out on cube specimens with a $10 \mathrm{~mm}$ edge. The specimens after curing for $72 \mathrm{~h}$ were attached to a pre-weighed metal plate with one side. The plate was placed in a thermostatic chamber with a constant temperature of $20 \pm 2{ }^{\circ} \mathrm{C}$ and controlled relative humidity of $70 \pm 5 \%$. The mass of the samples was measured every $12 \mathrm{~h}$.

As can be seen from the diagram of the dependence of mass growth (Figure 4), directly related to the effect of carbonation on the aging time, the process of calcium hydroxide carbonation, obtained by the hydration of $\mathrm{CaO}$, after 20 days is practically stopped, reaching avalue of $3.1 \%$. At the same time, all the samples after vibration treatment are characterized by a stable increase in mass up to 100 days of aging. From the course of the carbonation process, it can be concluded that the most active is calcium hydroxide after $20 \mathrm{~min}$ of treatment in the vibro-activator. A further increase in vibro-treatment time does not lead to an increase in the activity of calcium hydroxide particles.

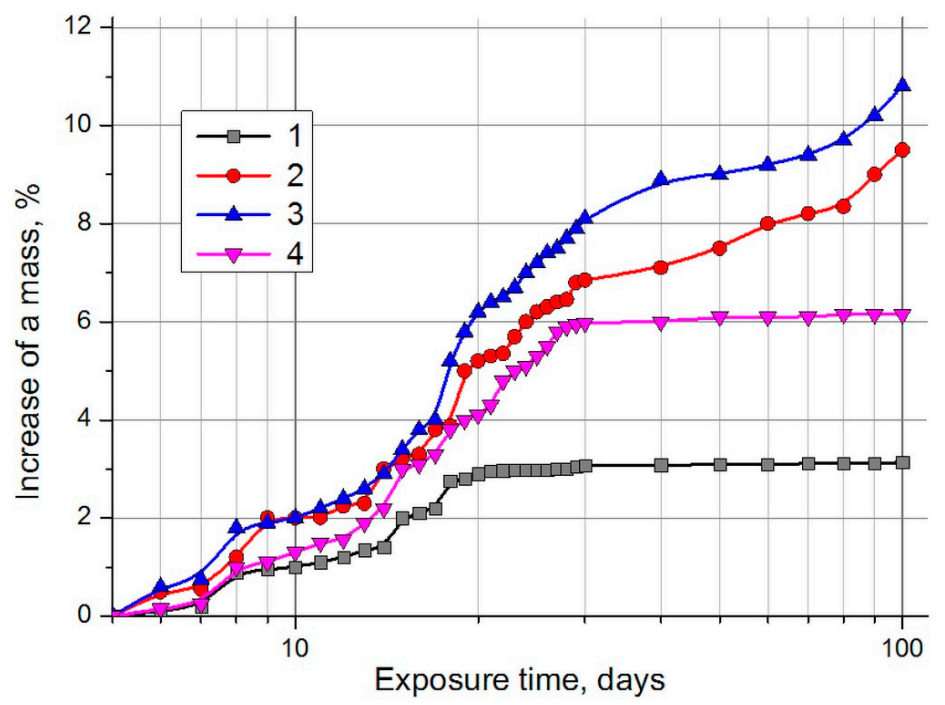

Figure 4. Influence of vibration treatment time $(\mathrm{min})$ on the degree of calcium hydroxide carbonation: 1-without treatment; 2-10 $\mathrm{min} ; 3-20 \mathrm{~min}$; $4-45 \mathrm{~min}$.

Such characteristics of calcium hydroxide carbonation are associated with the mechanism of lime carbonation [30,31], which occurs in several stages. At the first stage, calcium carbonate is formed on the surface of lime grains in the form of a dense layer as a result of the interaction of $\mathrm{H}_{2} \mathrm{CO}_{3}$ and $\mathrm{Ca}(\mathrm{OH})_{2}$, which is a reaction taking place at the boundary of contact of liquid and solid phases. 
Later on, in the presence of $\mathrm{CO}_{2}$ in the air, calcium carbonate passes into calcium hydrocarbonate $\mathrm{Ca}\left(\mathrm{HCO}_{3}\right)_{2}$.

The second stage is the interaction between the $\mathrm{CaOH}^{+}$and $\mathrm{CaHCO}^{+}$ions in the liquid phase. In this case, the lime grains are blocked and the reaction slows down. This can be explained by the fact that the determining factor in the interaction of calcium hydroxide and carbon dioxide is the specific surface of hydrated lime.

\section{Conclusions}

The vibro-processing of lime paste makes it possible to obtain lime of significantly increased activity and a noticeably finer grain size that accelerates the process of carbonation and increases the depth of conversion of hydroxide into calcium carbonate.

Changes in the duration of the vibration treatment of samples significantly affect the activity of calcium hydroxide particles. Thus, the optimal time for the vibrating treatment of hydrated lime is $20 \mathrm{~min}$; its further increase is not effective, because the activity of $\mathrm{Ca}(\mathrm{OH})_{2}$ is significantly reduced and the particles tend to form larger agglomerates.

Such a feature of the vibro-activated lime can be used for the deep cleaning of gas media from carbon dioxide, as well as other harmful products (e.g., $\mathrm{SO}_{2}$ ), i.e., when the reaction between $\mathrm{Ca}(\mathrm{OH})_{2}$ and the gas reagent takes place according to the scheme of the homogeneous heterophase process.

Author Contributions: Conceptualization, Y.Y., I.L. and R.J.; methodology, I.L.; validation, I.L.; formal analysis, Y.Y.; investigation, I.L. and T.K.; resources, Y.Y. and R.J.; data curation, T.K.; writing-original draft preparation, Y.Y.; writing-review and editing, R.J. and J.D.; visualization, J.D.; supervision, Y.Y. All authors have read and agreed to the published version of the manuscript.

Funding: This research received no external funding.

Conflicts of Interest: The authors declare no conflict of interest.

\section{References}

1. Macchia, A.; Bettucci, O.; Gravagna, E.; Ferro, D.; Albini, R.; Mazzei, B.; Campanella, L. Calcium hydroxide nanoparticles and hypogeum environment: Test to understand the best way of application. J. Nanomater. 2014, 2014, 1-10. [CrossRef]

2. Samanta, A.; Chanda, D.K.; Das, P.S.; Ghosh, J.; Mukhopadhyay, A.K.; Dey, A. Synthesis of nano calcium hydroxide in aqueous medium. J. Am. Ceram. Soc. 2016, 99, 787-795. [CrossRef]

3. Qin, C.; Yin, J.; An, H.; Liu, W.; Feng, B. Performance of extruded particles from calcium hydroxide and cement for $\mathrm{CO}_{2}$ capture. Energy Fuels 2012, 26, 154-161. [CrossRef]

4. Yakymechko, Y.; Jaskulski, R.; Lutsyuk, I. New ways of utilizing lime in modern building technology. Mater. Struct. Technol. 2019, 2, 61-69. [CrossRef]

5. Cazalla, O.; Rodriguez-Navarro, C.; Sebastian, E.; Cultrone, G.; Torre, M.J. Aging of lime putty: Effects on traditional lime mortar carbonation. J. Am. Ceram. Soc. 2004, 83, 1070-1076. [CrossRef]

6. Lanzón, M.; Madrid, J.A.; Martínez-Arredondo, A.; Mónaco, S. Use of diluted $\mathrm{Ca}(\mathrm{OH})_{2}$ suspensions and their transformation into nanostructured $\mathrm{CaCO}_{3}$ coatings: A case study in strengthening heritage materials (stucco, adobe and stone). Appl. Surf. Sci. 2017, 424, 20-27. [CrossRef]

7. Bhargavaramireddy, C.; Subramanian, K.S. Synthesis and properties of nano liming materials for reclamation of acid soils. J. Res. Angrau 2015, 43, 122-129.

8. Bhargavaramireddy, C.; Subramanian, K.S. Nano-lime for remediation of soil acidity: Synthesis and characterization. Curr. Adv. Agric. Sci. Int. J. 2016, 8, 39. [CrossRef]

9. Borsoi, G.; Lubelli, B.; van Hees, R.; Veiga, R.; Santos Silva, A. Evaluation of the effectiveness and compatibility of nanolime consolidants with improved properties. Constr. Build. Mater. 2017, 142, 385-394. [CrossRef]

10. Otero, J.; Starinieri, V.; Charola, A.E. Nanolime for the consolidation of lime mortars: A comparison of three available products. Constr. Build. Mater. 2018, 181, 394-407. [CrossRef]

11. Sakellariou, K.G.; Criado, Y.A.; Tsongidis, N.I.; Karagiannakis, G.; Konstandopoulos, A.G. Multi-cyclic evaluation of composite CaO-based structured bodies for thermochemical heat storage via the $\mathrm{CaO} / \mathrm{Ca}(\mathrm{OH})_{2}$ reaction scheme. Sol. Energy 2017, 146, 65-78. [CrossRef] 
12. Pozo-Antonio, J.S.; Fiorucci, M.P.; Ramil, A.; López, A.J.; Rivas, T. Evaluation of the effectiveness of laser crust removal on granites by means of hyperspectral imaging techniques. Appl. Surf. Sci. 2015, 347, 832-838. [CrossRef]

13. López-Arce, P.; Gomez-Villalba, L.S.; Pinho, L.; Fernández-Valle, M.E.; de Buergo, M.Á.; Fort, R. Influence of porosity and relative humidity on consolidation of dolostone with calcium hydroxide nanoparticles: Effectiveness assessment with non-destructive techniques. Mater. Charact. 2010, 61, 168-184. [CrossRef]

14. Bastone, S.; Chillura Martino, D.F.; Renda, V.; Saladino, M.L.; Poggi, G.; Caponetti, E. Alcoholic nanolime dispersion obtained by the insolubilisation-precipitation method and its application for the deacidification of ancient paper. Colloids Surf. A Physicochem. Eng. Asp. 2017, 513, 241-249. [CrossRef]

15. Taglieri, G.; Mondelli, C.; Daniele, V.; Pusceddu, E.; Trapananti, A. Synthesis and X-ray diffraction analyses of calcium hydroxide nanoparticles in aqueous suspension. Adv. Mater. Phys. Chem. 2013, 3, 108-112. [CrossRef]

16. Taglieri, G.; Mondelli, C.; Daniele, V.; Pusceddu, E.; Scoccia, G. Synthesis, textural and structural properties of calcium hydroxide nanoparticles in hydro-alcoholic suspension. Adv. Mater. Phys. Chem. 2014, 4, 50-59. [CrossRef]

17. Liu, T.; Zhu, Y.; Zhang, X.; Zhang, T.; Zhang, T.; Li, X. Synthesis and characterization of calcium hydroxide nanoparticles by hydrogen plasma-metal reaction method. Mater. Lett. 2010, 64, 2575-2577. [CrossRef]

18. Madrid, J.A.; Lanzón, M. Synthesis and morphological examination of high-purity $\mathrm{Ca}(\mathrm{OH})_{2}$ nanoparticles suitable to consolidate porous surfaces. Appl. Surf. Sci. 2017, 424, 2-8. [CrossRef]

19. Martínez-Ramírez, S.; Higueruela, L.R.; Cascales, I.; Martín-Garrido, M.; Blanco-Varela, M.T. New approach to nanolime synthesis at ambient temperature. SN Appl. Sci. 2019, 1, 105. [CrossRef]

20. Salvadori, B.; Dei, L. Synthesis of $\mathrm{Ca}(\mathrm{OH})_{2}$ nanoparticles from diols. Langmuir 2001, 17, 2371-2374. [CrossRef]

21. Darroudi, M.; Bagherpour, M.; Hosseini, H.A.; Ebrahimi, M. Biopolymer-assisted green synthesis and characterization of calcium hydroxide nanoparticles. Ceram. Int. 2016, 42, 3816-3819. [CrossRef]

22. Asikin-Mijan, N.; Taufiq-Yap, Y.H.; Lee, H.V. Synthesis of clamshell derived Ca(OH) 2 nano-particles via simple surfactant-hydration treatment. Chem. Eng. J. 2015, 262, 1043-1051. [CrossRef]

23. Tang, Z.-X.; Claveau, D.; Corcuff, R.; Belkacemi, K.; Arul, J. Preparation of nano-CaO using thermal-decomposition method. Mater. Lett. 2008, 62, 2096-2098. [CrossRef]

24. Amin Alavi, M.; Morsali, A. Ultrasonic-assisted synthesis of $\mathrm{Ca}(\mathrm{OH})_{2}$ and $\mathrm{CaO}$ nanostructures. J. Exp. Nanosci. 2010, 5, 93-105. [CrossRef]

25. Roy, A.; Bhattacharya, J. Synthesis of $\mathrm{Ca}(\mathrm{OH})_{2}$ nanoparticles by wet chemical method. Micro Nano Lett. 2010, 5, 131. [CrossRef]

26. Saoud, K.M.; Ibala, I.; El Ladki, D.; Ezzeldeen, O.; Saeed, S. Microwave assisted preparation of calcium hydroxide and barium hydroxide nanoparticles and their application for conservation of cultural heritage. In Digital Heritage. Progress in Cultural Heritage: Documentation, Preservation, and Protection; Lecture Notes in Computer Science; Ioannides, M., Magnenat-Thalmann, N., Fink, E., Žarnić, R., Yen, A.-Y., Eds.; Springer International Publishing: Cham, Switzerland, 2014; pp. 342-352, ISBN 978-3-319-13694-3.

27. Kilic, S.; Toprak, G.; Ozdemir, E. Stability of $\mathrm{CaCO} 3$ in $\mathrm{Ca}(\mathrm{OH}) 2$ solution. Int. J. Miner. Process. 2016, 147, 1-9. [CrossRef]

28. Nicoleau, L.; Nonat, A. A new view on the kinetics of tricalcium silicate hydration. Cem. Concr. Res. 2016, 86, 1-11. [CrossRef]

29. Galmarini, S.; Bowen, P. Atomistic simulation of the adsorption of calcium and hydroxyl ions onto portlandite surfaces-Towards crystal growth mechanisms. Cem. Concr. Res. 2016, 81, 16-23. [CrossRef]

30. Van Balen, K.; Van Gemert, D. Modelling lime mortar carbonation. Mater. Struct. 1994, 27, $393-398$. [CrossRef]

31. Van Balen, K. Carbonation reaction of lime, kinetics at ambient temperature. Cem. Concr. Res. 2005, 35, 647-657. [CrossRef]

(C) 2020 by the authors. Licensee MDPI, Basel, Switzerland. This article is an open access article distributed under the terms and conditions of the Creative Commons Attribution (CC BY) license (http://creativecommons.org/licenses/by/4.0/). 